\title{
1. Introduction: establishing the art of contextualizing CSR as a research area Anders Örtenblad
}

The main focus of this book is on the universality of corporate social responsibility (CSR) and whether all organizations around the world - regardless of which national culture, religion, sector, industry and so on, they exist in - could be recommended to adopt the exact same version of CSR. If the same version of CSR cannot be recommended for all contexts, then there is reason to develop a model for each individual generalized context.

Thus, instead of focusing on what organizations in various contexts have interpreted that CSR means and how they are practicing CSR, the focus here is on how organizations in various generalized contexts should practice CSR when the context is considered. Without such knowledge there is a clear risk that organizations may adopt something that would be devastating for them or avoid adopting something that would be beneficial. A basic assumption in this book is therefore that it cannot be assumed that organizations always know what is best for them, nor that they always act in a way that is in their own (or others') interest.

In this introductory chapter, the above vignette is explained in more detail, and the remainder of the book is presented. CSR, and how it will be defined throughout this book, is elaborated further on in this chapter. As a background to the reading of this first chapter of the book, it might be helpful to know that a slightly modified version of Moon's (2014) definition of CSR, in terms of seven aspects of CSR, is used throughout the book.

CSR is dealt with here as an 'idea', and literature on management ideas and management fashions is referred to. However, it must be noted, and even underlined, that this in no way means that CSR is treated as 'only' a management fashion. Nevertheless, it seems reasonable to regard CSR as 'fashionable', which is to be understood merely as an observation of the recent popularity that this idea or concept has gained, and not as a valueloaded statement (see, for example, Abrahamson 1996).

In the first few sections in this introductory chapter, the above vignette is discussed and elaborated on in more detail. The final section of the chapter introduces the remainder of the book in terms of the chapter contributions. 


\section{WHY THE QUESTION OF UNIVERSALITY OF CSR IS IMPORTANT}

CSR has lately become a hugely popular concept (see, for example, Görpe and Öksüz, Chapter 2 in this volume). As Görpe and Öksüz (Chapter 2 in this volume) note, the more irresponsible organizations are, the more reason there could be said to be for organizations to develop plans and strategies for CSR (see also Athanasopoulou and Selsky, Chapter 4 in this volume).

Something which is often the case with popular ideas is that in the literature they are described as if they were universally applicable. The following quotes show that this may also be the case for CSR, in at least some of the literature: 'A company that intends to remain competitive in its industry must be seen to be socially responsible' (Idowu and Papasolomou 2007, p. 145); 'We can turn to more independent research about the benefits of CSR. The positive reports in a wide range of examples and in a variety of industries are worth considering. I have not been able to find any research that shows CSR to be a bad thing' (Holme 2010, p. 181); 'Corporate social responsibility (CSR) is of increasing concern and holds strategic implications to companies across industries' (Hsu 2012, p. 189). However, if any organization believes that CSR could work for them, without actors first reflecting upon it, then there is a risk that the organization might adopt elements that could prove to be fatal. For this reason there is a need to explore whether a broad, general model of CSR is relevant for organizations in various generalized contexts and, if not, then there is also reason to suggest what kind of CSR model would fit organizations in the generalized contexts where the general model of CSR has shown not to fit fully.

Another thing that is common among popular ideas is that they are vague, which also has been argued to be true for CSR (for example, Frankental 2001; Coelho et al. 2003; Windell 2007; Grafström and Windell 2011; Furusten et al. 2013; Guthey and Morsing 2014). The vagueness offers freedom (cf. Røvik 1996; Alvarez 1998; Scarbrough and Swan 2001), in that there is room for various actors to define CSR themselves, thus helping to make the CSR concept more universal. However, if anyone can apply and call anything CSR, then there is a risk that the good sides of CSR - for organizations as well as for society - will get lost. And, again, there is a risk that aspects would be adopted that are devastating for the organization or, for that matter, that essential and even vital elements of CSR are overlooked. For these reasons, it is important that there is a relatively clear definition of CSR, which, even if it does not fit all generalized contexts around the world, could be used as a starting point 
for examinations of whether or not and to what extent it fits organizations in various generalized contexts.

The context has been acknowledged in management and organization studies for quite some time now (for example, Adler 1983; Guillen 1994; Redding 1994; Johns 2001; March 2005). There are different ways of taking the context into account in studies of ideas such as CSR. One way is to descriptively study how CSR actually is practiced in various contexts. There are numerous works that attest to the different forms that CSR takes in different contexts (for example, Gjølberg 2010). This is also something that many of the chapters in this book suggest. For example, Athanasopoulou and Selsky (Chapter 4 in this volume) argue that there are many descriptive studies of CSR in different particular contexts; Davidson (Chapter 3 in this volume) discusses why CSR may be defined and practiced differently in different countries around the world; and Görpe and Öksüz (Chapter 2 in this volume) suggest that CSR is focused on different matters in different European countries. Another way to take the context into account is to figure out, normatively, what CSR should mean and accordingly how it should be practiced in different contexts (in this book proposed mainly by Visser, Chapter 19; see also Gottschalk, Chapter 18 in this volume), a type of study for which this book tries to offer examples.

'Context' refers here to a collection of implicit assumptions about a particular setting, its meaning and quality (Firat 2003). Contextual knowledge, when taken from one context or setting, can be recontextualized, which involves a sophisticated discursive shift in which a discourse generated in one context produces different meanings and consequences when imposed in an alternative context (Asimakou and Oswick 2010), or decontextualized, that is, when knowledge is transferable across situations (Ackermann 1991). In the latter case, knowledge is removed from a particular context so that the implicit assumptions and contextual knowledge become separate from the immediate here-and-now setting, thereby losing their contextuality and, according to Ackermann (1991), becoming abstract. 'Generalized context' in the present book refers to a context that on a general level can be said to be shared by many organizations. Examples of such generalized contexts are particular religions (such as Islam and Buddhism - Perry and Ahmad, Chapter 5 in this volume), national cultures (such as those of Canada, Chad, China, Colombia or Czech Republic), sectors (such as the public sector) and industries (such as the food processing industry - Hall, Chapter 8 in this volume - and the shipping industry - Lekakou et al., Chapter 9 in this volume). Such generalized contexts can also be combined, which some argue is preferable (Athanasopoulou and Selsky, Chapter 4 in this volume), and which, for 
example, Fafaliou and Aroni (Chapter 12 in this volume) have done in their chapter on the Greek shipping business.

\section{AN ACADEMIC APPROACH TO THE IDEA OF CSR}

There is a tendency for concepts such as CSR in the management area to be considered as one-sidedly positive by the majority of authors, and as one-sidedly negative by a few authors. This applies, for example, to the learning organization (Driver 2002; Örtenblad 2013) and knowledge management (Örtenblad 2014). As was shown above, there are works that indicate that CSR is something that is good for all, which can represent the positive side of the literature. There are also works that are fully or mainly critical of CSR (for example, Frankental 2001; Coelho et al. 2003; Doane 2005). Among the critical arguments, there are those who argue that CSR is unachievable in practice, that CSR is merely another way for organizations to increase their profits, and that CSR merely gives organizations legitimacy whereas no real changes come from it. (See also Athanasopoulou and Selsky, Chapter 4 in this volume, who refer to a type of critique against CSR that sees CSR as a Trojan horse to colonize political space with exemplary social projects that are detached from core profit-driven strategy.) Among other possible arguments against CSR that one could bring up is an argument that is similar to a critique that can be made against charity, namely that it does not lead to any true changes but gives people a good conscience, which stops them from being active in fighting for more radical changes.

The approach taken in this book could be said to be an academic approach, in which it is neither taken for granted that CSR is onesidedly positive, nor that it is one-sidedly negative. Thus, unlike the many researchers who tend to be skeptical of ideas like CSR (cf. Nicolai and Röbken 2005, pp. 416-17), this book agrees with those who claim that fashionable ideas might actually add at least some value to the organizations in which they are used (for example, Kieser 1997; Collins 2000; Sorge and van Witteloostuijn 2004, p. 1208) and, thus, that there are both pros and cons to CSR. Thus, this book has a more constructive yet reflective and critically examining orientation. In this sense, this book connects to the quite large number of more nuanced works on CSR that exist (for example, Hilton 2003; Utting 2005; Tencati et al. 2008; Devinney 2009), of which some have applied something that we could call a contingency perspective of or a contextual approach to CSR (for example, Boulouta and Pitelis 2014). The relevance of CSR must be examined in each individual case or, at the least, for organizations in each generalized 
context. In such relevance examination of CSR for particular generalized contexts, the above arguments - the positive as well as the negative - are most likely relevant, as are other positive and negative arguments. Most of all, though, knowledge about the particular generalized context must be taken into account in such examination and when suggesting a model of CSR that is relevant to the particular generalized context.

\section{A NEED FOR RESEARCHER INTERVENTION}

We could, of course, trust people's own ability to contextualize CSR. If we did, then those descriptive studies of how CSR is practiced in different generalized contexts could simply be the starting point for other organizations in the same generalized context to implement CSR (for example, how definitions and practices of CSR may differ in various European countries - see Görpe and Öksüz, Chapter 2 in this volume - or throughout the world - see Davidson, Chapter 3 in this volume). However, for various reasons, some of which have been mentioned above, organizational actors cannot be assumed always to be rational or to do what is best for them. They may lack knowledge and for this reason adopt unbeneficial elements of CSR or avoid adopting elements of CSR that may be beneficial for them. They may, for reasons that connect to limited rationality (such as comfortability, and the like), avoid adopting beneficial elements, and organizational actors may intentionally or unintentionally prioritize their own individual interests over the organization's (or the society's) interests. There is always a risk that organizational actors may adopt a whole idea or elements of the idea that may help to put the organization in a favorable light but actually would be harmful for the organization to put in practice. Likewise, organizations may reject CSR or important elements of it, which for convenience reasons they may claim are not applicable, while it could be very beneficial to adopt these. There may also be occasions when organizational actors use an idea that is as vague as CSR is, as was taken up above, for purposes of seduction. Managers can present different versions of the idea to different groups, and thereby the same vague idea can satisfy different interests (see, for example, Astley and Zammuto 1992; Kelemen 2000).

The above reasoning may seem to imply that researchers generally can be assumed to have more knowledge on how critical examinations of such an idea as CSR could be conducted and that they also can be assumed to be less biased. For these reasons, researchers should contribute to the contextualization of CSR. However, researchers hardly know more about the exact situation or need of the particular organization, and, thus, it 
might not be reasonable to request researchers to customize CSR for each individual organization's needs. But they can be assumed to have more knowledge on what organizations within particular generalized contexts need, and also on how to judge and advise on the relevance of CSR.

While it definitely is a good idea to involve researchers in contextualizing CSR to fit various particular generalized contexts, there may be a risk in putting too much belief in them. At the least, researchers also need to learn how best to critically examine CSR. As a complement to researchers' interference in the contextualization of CSR, there is also reason to start educating students in how such a critical examination could be conducted (see Lamb et al. 2016; Örtenblad et al. 2015). Nevertheless, a basic assumption within the present book is that researchers, better than others, in an unbiased and knowledgeable way, are capable of advising on the relevance of a particular definition of CSR to organizations in different generalized contexts.

The exact output of such a critical examination might vary from case to case. The organizations within a particular context might be advised to change in accordance with CSR, the definition of CSR that is used might be modified to better fit organizations in the particular generalized context, changes to both the CSR definition and the context/organizations might be suggested, or no changes whatsoever may be recommended. CSR might be more relevant for organizations within a certain generalized context than to organizations within another generalized context. Even if the common definition does not always (or even seldom) need to be adapted to fit organizations in particular contexts, this is also important knowledge. Some answers to these and similar questions will be offered further on in this book.

\section{A COMMON, OVER VIEW DEFINITION OF CSR}

To be able to compare contexts and, thus, to make it possible to examine the degree to which CSR is universal, there is a need for an inclusive, broad definition of the concept. For this reason Moon's suggestion of what is common for definitions of CSR is used as a starting point:

Numerous definitions of CSR are offered by academics and commentators, and by business, civil society, governmental and consulting organizations. Overall, the definitions capture the following key features:

- business responsibility to society (i.e. being accountable);

- business responsibility for society (i.e. in compensating for negative impacts and contributing to societal welfare); 
- business responsible conduct (i.e. the business needs to be operated ethically, responsibly and sustainably);

- business responsibility to and for society in broad terms (i.e. including environmental issues); and

- the management by business of its relationships with society. (Moon 2014, p. 4: emphases in original)

In order to make it easier to examine the relevance of these five points for organizations in various contexts, below is a slightly revised version of Moon's five points, in terms of seven aspects of CSR, which is the common definition of CSR used in the present book. CSR means:

1. being accountable;

2. compensating for their own negative impacts;

3. compensating for others' negative impacts;

4. contributing to societal welfare;

5. operating their business in an ethically, responsible and sustainable way;

6. taking responsibility for society and the environment in broad terms;

7. managing by business its relationships with society.

This definition or model of CSR will sometimes, in this book, be referred to as the 'seven aspects model' and sometimes as 'Moon's seven aspects', or the like. An organization that can be said to practice all of these seven aspects has thus adopted the whole of this book's definition of CSR, while an organization that practices some of the seven aspects but not others has partly adopted this book's definition of CSR.

\section{OVERALL AIMS AND MAIN RESEARCH APPROACH}

Rather than how CSR actually is practiced in organizations in different generalized contexts, this book discusses whether or not/to what extent organizations in different generalized contexts could and should practice CSR and how a given general model of CSR might have to be adapted to make complete sense in these different generalized contexts.

The overall aims of this book are: (1) to highlight and acknowledge the need for examining the relevance of CSR for organizations in different generalized contexts as an emerging research field; (2) to explore the universality of CSR; (3) to offer knowledge (as well as support for further knowledge-seeking) on how the general model of CSR needs to be 
adapted to become relevant to organizations within particular generalized contexts; and (4) to begin work on constructing a contingency model of the relevance of CSR for organizations in various generalized contexts.

To accomplish this, a number of contributors have studied CSR in various particular generalized contexts. They have been interested in finding out whether organizations in general in the generalized context that they have chosen to study can already be assumed to practice CSR in terms of the seven aspects model, and whether or not and to what extent they would recommend that the organizations in the chosen context that have an ambition to adopt CSR should adopt and practice each of the seven aspects of CSR. By dealing with both of these questions, the actions that any organization in the generalized context at stake should take can be outlined more easily and clearly. Moreover, such an approach helps in advising on the relevance in general of the CSR idea, for the generalized contexts studied. This approach also helps to answer questions such as whether there is a need to contextualize the seven aspects model of CSR to make it fit organizations in any particular generalized context, whether or not all of the seven aspects are relevant for the context at stake, whether all are equally important, and whether there is any aspect of CSR that is not included in the original model but that needs to be included in order to make it work for organizations in the particular generalized context.

\section{THE REMAINDER OF THE BOOK}

\section{Part I: Background and Introduction}

Part I of the book comprises an introduction and background and contains three chapters in addition to this one. In Chapter 2, 'Corporate social responsibility as concept and activity: an overview', Serra Görpe and Burcu Öksüz discuss reasons for organizations to engage in CSR and offer a background to the current interest in CSR in terms of putting CSR into a historical perspective. Further, Görpe and Öksüz discuss what CSR is and, consequently, how this concept could be defined, how CSR can be communicated, CSR thresholds, and how CSR may best be implemented in organizations. In Chapter 3, 'The importance of context in understanding CSR', D. Kirk Davidson argues that the context must be taken into account when understanding CSR. Davidson presents an eight-element tool to help understand why CSR is practiced in the way it is in any country, religion or culture, which consists of history, religions and philosophies, social norms, geography, political structures, level of economic development, civil society institutions, and safety net provisions. In 
Chapter 4, 'The social context in CSR research: a contextualist approach with critical applications', Andromachi Athanasopoulou and John W. Selsky argue for the importance of taking the social context into account when studying CSR and outline a framework for how more contextsensitive research on CSR can be conducted. Athanasopoulou and Selsky argue that such research should be more multi-level and multi-perspective, as well as more critical.

\section{Part II: Corporate Social Responsibility in Context}

Part II of the book contains chapters on the relevance of CSR for some particular generalized contexts, and consists of four subsections. All chapters use the seven aspects model of CSR as the starting point for discussions on whether organizations in the given generalized context without having made efforts to adopt CSR nevertheless can already be said to practice the seven aspects, and on whether or not - and, if so, to what extent - organizations in the given generalized context that have ambitions to adopt CSR should practice each and every one of the seven aspects, according to the authors' expertise. In short, the chapters in Part II deal with CSR both in terms of 'what is' and 'what should be' in some particular generalized contexts.

Section A focuses on religion, level of economic development and continent. In Chapter 5, 'Islamic and Buddhist perspectives of corporate social responsibility', Patsy Perry and Aini Ahmad present results from their studies of CSR in relation to two world religions, Islam and Buddhism, and organizations in contexts characterized by these two religions, respectively. In Chapter 6, 'CSR in developed versus developing countries: a comparative glimpse', Dima Jamali and Charlotte Karam compare CSR in developed and developing countries, but their focus is on the existence of CSR and relevance for organizations in developing countries. In Chapter 7, 'Does diffusion cover differentiation? Looking into corporate social responsibility in Asia', Patrick Reinmoeller focuses on CSR in China and also makes some comparisons with CSR in the USA, and he discusses the existence of the seven aspects as well as their relevance for organizations in Asia more generally.

Section B discusses the relevance of CSR for organizations in some different industries. In Chapter 8, 'Corporate social responsibility in the food processing industry', George Michael Hall discusses whether the seven aspects are practiced and whether they should be practiced by organizations in the food processing industry, taken in its widest meaning from farm to fork. Chapter 9, 'Corporate social responsibility in the shipping industry', authored by Maria Lekakou, Ioannis Theotokas and Evangelia 
Stefanidaki, is one of two chapters in the book that deal with CSR in the shipping industry; in this chapter the authors deal with the shipping industry more generally, and not in any specific geographical region. Likewise, Chapter 10, 'Corporate social responsibility in the pharmaceutical industry', authored by Wen Li Chan, Jeremy Eng Tuck Cheah and Luiz Montanheiro, is one of two chapters in the book that deal with the pharmaceutical industry, and in this chapter the discussion is not limited to any certain geographical area.

Section $\mathrm{C}$ includes chapters that explicitly deal with more than one contextual variable (a research approach propounded by Athanasopoulou and Selsky, Chapter 4 in this volume) and in which the authors attempt to discuss the relevance of CSR not only to a particular industry but to a particular industry within a particular country. In Chapter 11, 'Corporate social responsibility in the ready made garments industry in Bangladesh', Fara Azmat and Mohammed Ziaul Haque critically examine the state of CSR in the ready made garments industry in a developing country: Bangladesh. Chapter 12, 'Corporate social responsibility in the Greek shipping business', authored by Irene Fafaliou and Tina Aroni, is the second chapter on CSR in the shipping industry, and in this chapter the authors focus on the specific case of the Greek shipping business, which is considered to be one of the most important players in the industry worldwide. Chapter 13, 'Corporate social responsibility in the Turkish pharmaceutical industry', authored by Serra Görpe and Burcu Öksüz, is the second chapter on CSR in the pharmaceutical industry. The authors of this chapter discuss the existence of CSR in the pharmaceutical industry specifically in Turkey, and also whether or not all the seven aspects are relevant for organizations in this particular context.

Section D includes chapters on specific situations. In Chapter 14, 'The relevance of CSR in the case of an insurance firm and a motorcycle gang in Norway', Petter Gottschalk discusses the existence and relevance of CSR for organizations connected to the situation of 'an insurance firm and a motorcycle gang in Norway'. In Chapter 15, 'Fraud examiners in whitecollar crime investigations', Petter Gottschalk discusses the existence and relevance of CSR for organizations connected to the situation of 'fraud examiners in white-collar crime investigations'.

\section{Part III: Comments and Reflections}

Part III of the book contains chapters in which the authors reflect either on CSR in general or on previous parts of the book (especially the chapters in Part II). This part of the book starts off with two chapters commenting on the definition of CSR used in this book. In Chapter 16, 'Reflections on 
Table 1.1 The chapters in Part II, Sections A, B, C and D, on CSR in context, and the main source $(s)$ each chapter rests upon

\begin{tabular}{|c|c|c|c|c|}
\hline Section & Chapter & Authors & Context & $\begin{array}{l}\text { Main source/ } \\
\text { approach }\end{array}$ \\
\hline \multirow{3}{*}{$\begin{array}{l}\text { Section A } \\
\text { Religion/Level } \\
\text { of economic } \\
\text { development/ } \\
\text { Continent }\end{array}$} & 5 & $\begin{array}{l}\text { Patsy Perry and } \\
\text { Aini Ahmad }\end{array}$ & $\begin{array}{l}\text { Religion: Islam } \\
\text { and Buddhism }\end{array}$ & $\begin{array}{l}\text { Conceptual } \\
\text { comparison }\end{array}$ \\
\hline & 6 & $\begin{array}{l}\text { Dima Jamali } \\
\text { and Charlotte } \\
\text { Karam }\end{array}$ & $\begin{array}{l}\text { Developing } \\
\text { countries }\end{array}$ & $\begin{array}{l}\text { Literature } \\
\text { review }\end{array}$ \\
\hline & 7 & $\begin{array}{l}\text { Patrick } \\
\quad \text { Reinmoeller }\end{array}$ & Asia & $\begin{array}{l}\text { Literature, } \\
\text { case studies }\end{array}$ \\
\hline \multirow[t]{3}{*}{$\begin{array}{l}\text { Section B } \\
\text { Industry }\end{array}$} & 8 & $\begin{array}{l}\text { George Michael } \\
\text { Hall }\end{array}$ & $\begin{array}{l}\text { Food } \\
\text { processing } \\
\text { industry }\end{array}$ & Literature \\
\hline & 9 & $\begin{array}{l}\text { Maria Lekakou, } \\
\text { Ioannis Theotokas } \\
\text { and Evangelia } \\
\text { Stefanidaki }\end{array}$ & $\begin{array}{l}\text { Shipping } \\
\text { industry }\end{array}$ & $\begin{array}{l}\text { Empirical } \\
\text { study }\end{array}$ \\
\hline & 10 & $\begin{array}{l}\text { Wen Li Chan, } \\
\text { Jeremy Eng } \\
\text { Tuck Cheah and } \\
\text { Luiz Montanheiro }\end{array}$ & $\begin{array}{l}\text { Pharmaceutical } \\
\text { industry }\end{array}$ & Literature \\
\hline \multirow[t]{3}{*}{$\begin{array}{l}\text { Section C } \\
\text { Mixed contexts }\end{array}$} & 11 & $\begin{array}{l}\text { Fara Azmat and } \\
\text { Mohammed Ziaul } \\
\text { Haque }\end{array}$ & $\begin{array}{l}\text { Ready made } \\
\text { garments industry } \\
\text { in Bangladesh }\end{array}$ & $\begin{array}{l}\text { Literature and } \\
\text { newspaper } \\
\text { analysis }\end{array}$ \\
\hline & 12 & $\begin{array}{l}\text { Irene Fafaliou } \\
\text { and Tina } \\
\text { Aroni }\end{array}$ & $\begin{array}{l}\text { Greek shipping } \\
\text { business }\end{array}$ & $\begin{array}{l}\text { Empirical } \\
\text { study }\end{array}$ \\
\hline & 13 & $\begin{array}{l}\text { Serra Görpe } \\
\text { and Burcu } \\
\text { Öksüz }\end{array}$ & $\begin{array}{l}\text { Turkish } \\
\text { pharmaceutical } \\
\text { industry }\end{array}$ & $\begin{array}{l}\text { Empirical } \\
\text { study }\end{array}$ \\
\hline \multirow[t]{2}{*}{$\begin{array}{l}\text { Section D } \\
\text { Specific } \\
\text { situation }\end{array}$} & 14 & $\begin{array}{l}\text { Petter } \\
\quad \text { Gottschalk }\end{array}$ & $\begin{array}{l}\text { Insurance firm } \\
\text { and motorcycle } \\
\text { gang in Norway }\end{array}$ & Literature \\
\hline & 15 & $\begin{array}{l}\text { Petter } \\
\quad \text { Gottschalk }\end{array}$ & $\begin{array}{l}\text { White-collar } \\
\text { crime } \\
\text { investigations }\end{array}$ & Literature \\
\hline
\end{tabular}

the universality and philosophical foundations of the "corporate social responsibility" definition', Jared M. Hansen discusses the universality of CSR in relation to various definitions of CSR, and evaluates the particular definition that is used in this book. The other chapter commenting on the definition used is a bit more critical. Every good book should have a 


\section{Research handbook on corporate social responsibility in context}

'counter-argument', or 'counterimage' as Ohlsson and Rombach (2015) call it, and preferably it should appear in the same book. In this book the chapter that comes the closest to being such a counter-argument is, perhaps, Chapter 17, 'A comment on the use of the seven aspects of CSR'. In that chapter Jochen Weikert argues why the seven aspects model is not a good starting point for studies on whether CSR is relevant for organizations in various particular generalized contexts, and argues - more generally - that there are no simple prescriptions to be made around CSR.

In Chapter 18, 'Stages of corporate social responsibility', Petter Gottschalk suggests a four-stage model of maturity levels of organizations' approaches to CSR, a model that he also applies to the seven aspects model and, thus, these aspects are implicitly ranked according to maturity level. Thereafter, there are two chapters whose main focus is to comment on CSR in general, but that nevertheless include examinations of CSR for organizations in particular generalized contexts. First, in Chapter 19, 'The future of CSR: towards transformative CSR, or CSR 2.0', Wayne Visser shares his skepticism regarding what CSR so far has contributed, and discusses reasons why CSR has previously failed. Visser also shares his vision of what CSR may come to accomplish, in terms of 'CSR 2.0' (which is his own concept), a vision that he believes is about to come true. Visser also briefly discusses the relevance of CSR for small and medium-sized enterprises (SMEs). In Chapter 20, 'Against CSR: the meaning and meaninglessness of CSR in China', Shih-wei Hsu argues, on the basis of a case study of a Chinese company, that CSR is abused in the Chinese context and that this abuse is due to theoretical shortcomings of the CSR concept. Hsu also briefly presents a critical-historic review of the CSR concept, and examines the relevance of the seven aspects model for organizations in a Chinese context. In Chapter 21, 'Conclusions, a contingency model of CSR and recommendations for further research', Anders Örtenblad discusses possible answers to the research questions that were asked above in this introductory chapter, summarizes the conclusions from the chapters in Part II in terms of a contingency model of the relevance of CSR for organizations in various particular generalized contexts, and discusses areas for some further research.

\section{REFERENCES}

Abrahamson, E. (1996), 'Management fashion', Academy of Management Review, 21 (1), 254-85.

Ackermann, Edith K. (1991), 'From decontextualized to situated knowledge: revisiting Piaget's water-level experiment', in Idit Harel and Seymour Papert (eds), Constructionism, Norwood, NJ: Ablex Publishing Corporation, pp. 367-79. 
Adler, N.J. (1983), 'A typology of management studies involving culture', Journal of International Business Studies, 14 (2), 29-47.

Alvarez, José L. (1998), 'The sociological tradition and the spread and institutionalization of knowledge for action', in José L. Alvarez (ed.), The Diffusion and Consumption of Business Knowledge, London: Macmillan, pp. 13-57.

Asimakou, T. and C. Oswick (2010), 'The recontextualization of commercialization: the shifting discourse of an R\&D unit', International Journal of Sociology and Social Policy, $30(5 / 6), 280-91$.

Astley, W.G. and R.F. Zammuto (1992), 'Organization science, managers and language games', Organization Science, 3 (4), 443-60.

Boulouta, I. and C.N. Pitelis (2014), 'Who needs CSR? The impact of corporate social responsibility on national competitiveness', Journal of Business Ethics, 119 (3), 349-64.

Coelho, P.R.P., J.E. McClure and J.A. Spry (2003), 'The social responsibility of corporate management: a classical critique', American Journal of Business, 18 (1), 15-24.

Collins, David (2000), Management Fads and Buzzwords: Critical-Practical Perspectives, London: Routledge.

Devinney, T.M. (2009), 'Is the socially responsible corporation a myth? The good, the bad, and the ugly of corporate social responsibility', Academy of Management Perspectives, 23 (2), 44-56.

Doane, D. (2005), 'The myth of CSR', Global Policy Forum, 4 November, accessed 5 May 2016 at http://www.globalpolicy.org/socecon/tncs/2005/1104myth.htm.

Driver, M. (2002), 'The learning organization: Foucauldian gloom or utopian sunshine?', Human Relations, 55 (1), 33-53.

Firat, A. (2003), 'Information integration using contextual knowledge and ontology merging', doctoral dissertation, Massachusetts Institute of Technology, Cambridge, MA.

Frankental, P. (2001), 'Corporate social responsibility: a PR invention?', Corporate Communications: An International Journal, 6 (1), 18-23.

Furusten, Staffan, Andreas Werr, Matilda Ardenfors and Sabine Walter (2013), 'CSR and the consultancy sector: what is offered, and by whom?', in Mats Jutterström and Peter Norberg (eds), CSR as a Management Idea: Ethics in Action, Cheltenham, UK and Northampton, MA, USA: Edward Elgar Publishing, pp. 75-93.

Gjølberg, M. (2010), 'Varieties of corporate social responsibility (CSR): CSR meets the "Nordic Model"', Regulation \& Governance, 4 (2), 203-29.

Grafström, M. and K. Windell (2011), 'The role of infomediaries: CSR in the business press during 2000-2009', Journal of Business Ethics, 103 (2), 221-37.

Guillen, M.F. (1994), 'The age of eclecticism: current organizational trends and the evolution of managerial models', Sloan Management Review, 36 (1), 75-86.

Guthey, E. and M. Morsing (2014), 'CSR and the mediated emergence of strategic ambiguity', Journal of Business Ethics, 120 (4), 555-69.

Hilton, S. (2003), 'How brands can change the world', Journal of Brand Management, 10 (4), $370-77$.

Holme, C. (2010), 'Corporate social responsibility: a strategic issue or a wasteful distraction?', Industrial and Commercial Training, 42 (4), 179-85.

Hsu, K-T. (2012), 'The advertising effects of corporate social responsibility on corporate reputation and brand equity: evidence from the life insurance industry in Taiwan', Journal of Business Ethics, 109 (2), 189-201.

Idowu, S.O. and I. Papasolomou (2007), 'Are the corporate social responsibility matters based on good intentions or false pretences? An empirical study of the motivations behind the issuing of CSR reports by UK companies', Corporate Governance: The International Journal of Business in Society, 7 (2), 136-47.

Johns, G. (2001), 'In praise of context', Journal of Organizational Behavior, 22 (1), 31-42.

Kelemen, M. (2000), 'Too much or too little ambiguity: the language of total quality management', Journal of Management Studies, 37 (4), 483-98.

Kieser, A. (1997), 'Rhetoric and myth in management fashion', Organization, 4 (1), 49-74.

Lamb, P., A. Örtenblad and S-W. Hsu (2016), "Pedagogy as translation": extending the 


\section{Research handbook on corporate social responsibility in context}

horizon of translation theory', International Journal of Management Reviews, published ahead of print, DOI: 10.1111/ijmr.12098.

March, J.G. (2005), 'Parochialism in the evolution of a research community: the case of organization studies', Management and Organization Review, 1 (1), 5-22.

Moon, Jeremy (2014), Corporate Social Responsibility: A Very Short Introduction, Oxford: Oxford University Press.

Nicolai, A.T. and H. Röbken (2005), 'Scientification, immune responses, and reflection: the changing relationship between management studies and consulting', Journal of Organizational Change Management, 18 (5), 416-35.

Ohlsson, Östen and Björn Rombach (2015), 'The art of constructive criticism', in Anders Örtenblad (ed.), Handbook of Research on Management Ideas and Panaceas: Adaptation and Context, Cheltenham, UK and Northampton, MA, USA: Edward Elgar Publishing, pp. $149-70$.

Örtenblad, Anders (2013), 'Introduction. Putting the learning organization into context: an emerging research field', in Anders Örtenblad (ed.), Handbook of Research on the Learning Organization: Adaptation and Context, Cheltenham, UK and Northampton, MA, USA: Edward Elgar Publishing, pp. 3-21.

Örtenblad, Anders (2014), 'Introduction: towards the contextualization of knowledge management as a research field', in Anders Örtenblad (ed.), Handbook of Research on Knowledge Management: Adaptation and Context, Cheltenham, UK and Northampton, MA, USA: Edward Elgar Publishing, pp. 3-17.

Örtenblad, Anders, Peter Lamb and Shi-wei Hsu (2015), 'Empowering students to translate fashionable management ideas', in Anders Örtenblad (ed.), Handbook of Research on Management Ideas and Panaceas: Adaptation and Context, Cheltenham, UK and Northampton, MA, USA: Edward Elgar Publishing, pp. 477-85.

Redding, S.G. (1994), 'Comparative management theory: jungle, zoo, or fossil bed?', Organization Studies, 15 (3), 323-59.

Røvik, Kjell A. (1996), 'Deinstitutionalization and the logic of fashion', in Barbara Czarniawska and Guje Sevón (eds), Translating Organizational Change, Berlin: De Gruyter, pp. 139-72.

Scarbrough, H. and J. Swan (2001), 'Explaining the diffusion of knowledge management: the role of fashion', British Journal of Management, 12 (1), 3-12.

Sorge, A. and A. van Witteloostuijn (2004), 'The (non)sense of organizational change: an essay about universal management hypes, sick consultancy metaphors, and healthy organization theories', Organization Studies, 25 (7), 1205-31.

Tencati, A., A. Russo and V. Quaglia (2008), 'Unintended consequences of CSR: protectionism and collateral damage in global supply chains: the case of Vietnam', Corporate Governance: The International Journal of Business in Society, 8 (4), 518-31.

Utting, P. (2005), 'Corporate responsibility and the movement of business', Development in Practice, 15 (3/4), 375-88.

Windell, Karolina (2007), 'The commercialization of CSR: consultants selling responsibility', in Frank den Hond, Frank G.A. de Bakker and Peter Neergaard (eds), Managing Corporate Social Responsibility in Action: Talking, Doing and Measuring, Aldershot: Ashgate, pp. 33-51. 